\title{
Peningkatan kemampuan memecahkan masalah antara model penalaran kausal berbasis etnosains dan sains modern
}

\author{
Supriyadi $^{1,2}$, Haeruddin ${ }^{2}$, dan Nurjannah ${ }^{2}$ \\ ${ }^{1} J u r u s a n$ Pendidikan Fisika, Universitas Musamus \\ ${ }^{2}$ Program Studi Pendidikan Fisika, Universitas Tadulako \\ IJl. Kamizaun Mopah Lama, Merauke, Papua-Indonesia \\ 2J1. Soekarno-Hatta KM. 9, Palu, Sulawesi Tengah-Indonesia \\ Surat-e: adhie912@gmail.com
}

\begin{abstract}
Penelitian ini betujuan untuk mengetahui perbedaan kemampuan memecahkan masalah fisika antara model penalaran kausal berbasis etnosains dengan sains modern. penelitian ini menggunakan desain penelitian "The Non Equivalen Pretest-Postest Design". Populasi penelitian ini adalah seluruh siswa kelas X pada MA AlKhairaat Pusat Palu. Sampel dipilih secara Proportional Sample, dengan sampel penelitian adalah kelas XD dan kelas Xc. Hasil analisa data yang diperoleh adalah kemampuan memecahkan masalah fisika kelas eksperimen pertama rata-rata 17,II dengan standar deviasi 3,82 dan kelas eksperimen kedua rata-rata I4,30 dengan standar deviasi 4,07. Berdasarkan hasil pengujian hipotesis diperoleh $t_{h i t}=2,03$ dengan kriteria adalah terima $H_{\circ}$ jika $2,02<\mathrm{t}<2,02$ dan tolak $\mathrm{H}_{\mathrm{o}}$ dalam hal lainnya. nilai thitung berada di luar penerimaan $\mathrm{H}_{\mathrm{o}}$. Dengan demikian $\mathrm{H}_{\mathrm{o}}$ ditolak sedangkan $\mathrm{H}_{\mathrm{I}}$ diterima dan dapat disimpulkan bahwa terdapat perbedaan kemampuan memecahkan masalah antara model penalaran kausal berbasis etnosains dengan sains modern.
\end{abstract}

This study aims to determine the difference between the ability to solve problems of physics-based models of causal reasoning etnosains with modern science. The design of this research study "The Non equivalent PretestPosttest Design". The study population was all students of class X in the MA Al-Khairaat Palu Center. Samples selected Proportional Sample, the sample is first class and the class $\mathrm{X}_{\mathrm{C}} \mathrm{X}_{\mathrm{D}}$. Results of analysis of the data obtained is the ability to solve the problem of experimental physics first class average of I7.II with a standard deviation of 3.82 and the second experimental class average of 14.30 with a standard deviation of 4.07. Based on the hypothesis testing results obtained thit $=2.03$ with the criteria is accept $\mathrm{H}_{\mathrm{o}}$ if $-2.02<\mathrm{t}<2.02$ and reject $\mathrm{H}_{\mathrm{o}}$ in other cases. tcount is outside the reception $\mathrm{H}_{\circ}$. Thus $\mathrm{H}_{\mathrm{o}}$ is rejected while $\mathrm{H}_{\mathrm{I}}$ is accepted and concluded that there are differences between the models of problem-solving skills-based causal reasoning etnosains with modern science.

Kata kunci: Penalaran Kausal, Memecahkan Masalah.

\section{Pendahuluan}

Keberhasilan proses pembelajaran IPA khususnya fisika di sekolah sangat dipengaruhi oleh latar belakang budaya yang dimiliki oleh siswa atau masyarakat tempat sekolah berada ${ }^{[1]}$. Guru perlu mengaitkan antara antara konsep fisika yang siswa pelajari di sekolah dengan latar belakang kebudayaan yang ada di lingkungan siswa sendiri. Pembelajaran sains di sekolah perlu memadukan paradigma ilmiah dengan cara pandang siswa tentang istilah-istilah dalam sains dan gejala-gejala fisis yang terjadi di alam sekitarnya.

Pengalaman menunjukkan bahwa apabila pengetahuan yang dipelajari di sekolah dirasakan manfaatnya bagi kehidupan siswa, ia akan termotivasi untuk mempelajari, bahkan ingin mencari lebih banyak lagi ${ }^{[2]}$. Pengetahuan konseptual mereka telah dibentuk bertahun-tahun dari pengalaman sehari-hari dan melalui pengetahuan tradisi yang diwariskan secara turun-menurun. Oleh karena itu, lingkungan sosial-budaya siswa perlu mendapat perhatian serius dalam mengembangkan pendidikan sains di sekolah karena di dalamnya terpendam sains asli yang dapat berguna bagi kehidupannya. Dengan demikian, pendidikan sains akan betul-betul bermanfaat bagi siswa itu sendiri dan bagi masyarakat luas ${ }^{[3]}$.

Berdasarkan penjelasan di atas, proses pembelajaran fisika, seharusnya lebih diarahkan kepada pemecahan masalah. Karena fisika bukan sekedar hafalan ataupun pemahaman, tetapi juga butuh analisis terhadap permasalahan-permasalahannya. Jika siswa dibiarkan lebih aktif dalam memecahkan masalah fisika, tentunya pembelajaran fisika akan lebih menarik bagi siswa, terlebih jika masalah yang diberikan, merupakan masalah yang berkaitan, atau yang terdapat dalam kebudayaan 
lokal siswa, yang masih kurang diterapkan dalam pembelajaran di sekolah.

Kemampuan memecahkan masalah, sangat berkaitan dengan daya nalar siswa. Kemampuan penalaran merupakan kemampuan siswa untuk mengaitkan suatu kasus dengan kasus yang lain, sehingga dapat ditarik suatu kesimpulan. Sehingga, untuk meningkatkan kemampuan memecahkan masalah pada siswa, maka harus lebih sering membuat siswa menggunakan kemampuan penalarannya.

Dalam pelaksaannya peneliti akan melihat perbedaan antara model penalaran kausal berbasis etnosains dengan model penalaran kausal berbasis sains modern. Model penalaran kausal berbasis etnosains merupakan suatu strategi pembelajaran yang muncul sebagai alternatif dan dianggap dapat membantu siswa untuk dapat memecahkan masalah fisika dengan mengaitkan konsep yang ada dengan gejala-gejala fisika yang ada dan berkembang dalam kebudayaan siswa. Sedangkan model penalaran kausal berbasis sains modern merupakan strategi pembelajaran dimana pengetahuan sains bersumber dari kerja ilmiah para ilmuan dengan menggunakan metode ilmiah. Keduanya membawa kepada perubahan pola dan strategi dalam pembelajaran fisika. Dimana fisika bukan hanya sekedar teori tetapi juga memiliki hubungan yang sangat erat dengan kehidupan sehari-hari siswa.

\section{Kajian Pustaka}

\section{Model Penalaran Kausal Berbasis Etnosains}

Inti dari fisika dan ilmu sains lainnya adalah hubungan sebab akibat (kausal) ${ }^{[4]}$. Hubungan kausal tersebut menentukan fungsi dari konsep fisika dan bidang sains yang lain. Ethnoscience dalam kamus Anthropologi, diartikan sebagai suatu studi kebudayaan dengan cara pendekatan menggunakan pengetahuan yang sesuai dengan kebudayaan masyarakat yang dipelajari ${ }^{[5]}$. Melalui pemanfaatan sains tradisional (ethnoscience), pengetahuan dengan mudah dikombinasikan dengan kebudayaan berdasarkan perilaku masyarakatnya.

Model penalaran kausal berbasis etnosains adalah media pembelajaran fisika dengan menggunakan model pemecahan masalah yang berdasar pada hubungan sebab akibat untuk menentukan fungsi dari konsep fisika, memprediksikan, menyimpulkan, dan menjelaskan gejala atau peristiwa fisika yang dihadapi atau diamati berdasarkan contoh kebudayaan masyarakat lokal (etnosains) yang saling berhubungan dalam memecahkan masalah fisika.

\section{Model Penalaran Kausal Berbasis Sains Modern}

Hubungan kausal adalah hubungan antara penyebab (cause) dan akibatnya (effect). Tiga prinsip utama yang terkait dengan hubungan kausal adalah prinsip prioritas, prinsip kovariasi (cooccurrence), dan prinsip mekanisme ${ }^{[6]}$. Ogawa menyatakan bahwa "sains" bukanlah budaya asli orang Jepang, tetapi merupakan budaya import dari negara Barat yang masuk ke Jepang semenjak pertengahan abad ke-I9, meskipun faktanya sekarang orang Jepang dapat mempelajari sains karena sains dipandang dari perspektif multicultural ${ }^{[3]}$.

Model penalaran kausal berbasis sains modern adalah media pembelajaran fisika dengan menggunakan model pemecahan masalah yang berdasar pada hubungan sebab akibat untuk menentukan fungsi dari konsep fisika, memprediksikan, menyimpulkan, dan menjelaskan gejala atau peristiwa fisika yang dihadapi atau diamati berdasarkan contoh pengetahuan ilmiah yang telah dibuktikan secara ilmiah oleh para ilmuan.

\section{Kemampuan Memecahkan Masalah}

Menurut Hung dan Jonassen memecahkan masalah menuntut kemampuan untuk dapat melihat sebab akibat atau kausal antar berbagai konsep sehingga pada akhirnya dapat menemukan kunci pembuka masalah ${ }^{[3]}$.

Dalam penelitian ini, kemampuan memecahkan masalah yang dimaksud adalah kemampuan siswa dalam menggunakan pengetahuan-pengetahuan dan konsep yang dipahami untuk memecahkan masalah yang berhubungan dengan permasalahan dalam kehidupan sehari-hari. Kemampuan pemecahan masalah siswa akan diukur dengan menggunakan tes dalam bentuk uraian. skor penilaian yang diberikan untuk setiap item soal dengan skor minimal nol dan skor maksimal dua.

\section{Metode Penelitian}

\section{Desain Penelitian}

Penelitian ini mengunakan metode kuasi eksperimen dengan menggunakan dua kelas eksperimen. Adapun desain penelitian adalah menggunakan desain penelitian "The Non Equivalen Pretest-Postest Design" atau Rancangan Prates-Pascates yang tidak Ekuivalen, yaitu menggunakan kelas-kelas yang sudah ada sebagai kelompoknya, dengan memilih kelas-kelas yang diperkirakan sama keadaan/kondisinya, dalam hal ini sama berdasarkan tingkat kecerdasan. Satu kelas berfungsi sebagai kelas eksperimen pertama dan satu kelas sebagai kelas eksperimen kedua.

Adapun desainnya menurut Sugiyono adalah sebagai berikut ${ }^{[8]}$ : 
Tabel I. Desain Penelitian

\begin{tabular}{cccc}
\hline Kelas & Tes Awal & Perlakuan & Tes Akhir \\
\hline $\mathrm{A}$ & $\mathrm{O} \longrightarrow$ & $\mathrm{X}_{\mathrm{I}} \longrightarrow$ & $\mathrm{O}$ \\
$\mathrm{B}$ & $\mathrm{O} \longrightarrow$ & $\mathrm{X}_{2} \longrightarrow$ & $\mathrm{O}$ \\
\hline
\end{tabular}

Keterangan :

$\mathrm{X}_{\mathrm{I}}$ : Perlakuan untuk kelas eksperimen dengan menggunakan model penalaran kausal berbasis etnosains.

$\mathrm{X}_{2}$ : Perlakuan untuk kelas eksperimen dengan menggunakan model penalaran kausal berbasis sains modern.

O: Tes awal dan tes akhir

\section{Populasi dan Sampel}

Populasi penelitian ini adalah seluruh siswa kelas $\mathrm{X}$ MA Al-Khairaat Pusat Palu yang tersebar dalam empat kelas dan terdaftar pada tahun ajaran 2011/2012. Sampel dalam penelitian ini adalah siswa kelas $\mathrm{X}_{\mathrm{c}}$ dan $\mathrm{X}_{\mathrm{d}}$, dimana dua kelas tersebut dipilih dengan teknik Proportional Sample.

\section{Instrumen Penelitian} lain:

Instrumen yang digunakan dalam penelitian ini antara

I) Perangkat pembelajaran penalaran kausal berbasis etnosains dan berbasis sains modern. Meliputi silabus, Rencana Pelaksanaan Pembelajaran (RPP), LKS dan bahan ajar.

2) Tes kemampuan memecahkan masalah fisika dengan konteks atau materi yang diajarkan dimana pada penelitian ini materi yang diajarkan adalah materi suhu dan kalor.

\section{Analisa Data}

Uji yang digunakan dalam penelitian ini antara lain;

a. Uji persyaratan Analisis : Uji Normalitas dan Homogenitas

b. Uji Hipotesis

\section{Hasil Penelitian dan Pembahasan}

Berdasarkan hasil pengujian hipotesis yang telah dilakukan setelah diberikan perlakuan pada kedua kelas, terdapat perbedaan kemampuan memecahkan masalah fisika antara model penalaran kausal berbasis etnosains dan model penalaran kausal berbasis sains modern yang signifikan. Pada tes akhir kemampuan memecahkan masalah fisika, skor rata-rata tes akhir pada kelas eksperimen pertama berbeda dengan kelas eksperimen kedua. Hal ini dapat dibuktikan dengan ditolaknya pasangan hipotesis ho yaitu diperoleh nilai dari thitung $>$ tabel dan diterima pasangan hipotesis h. Selain itu, dapat pula dilihat pada nilai rata-rata tes akhir siswa kelompok ekperimen dan kontrol.

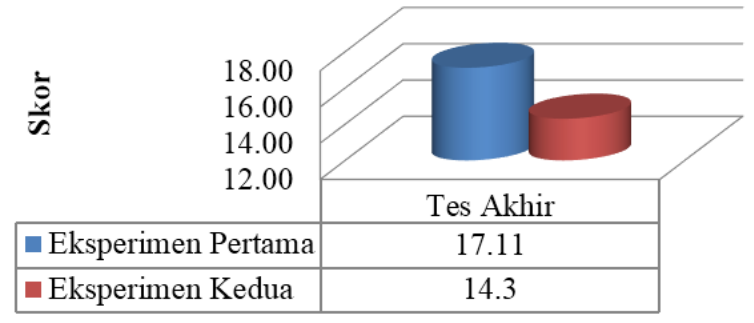

Gambar I. Grafik Analisis Rata-rata Skor Tes Akhir dari Kedua kelas Eksperimen

Perbedaan kemampuan memecahkan masalah fisika oleh siswa pada kedua kelas dipengaruhi atau disebabkan oleh peran basis model penalaran kausal yang diterapkan pada masing-masing kelas. Model penalaran kausal berbasis etnosains menuntun siswa untuk dapat menganalisis soal pemecahan masalah dan menyelesaikan soal dengan cara yang sistematis. Hal ini membuat siswa lebih tertarik dalam memahami konsep fisika. Ketertarikan siswa terhadap materi dapat terlihat pada proses pembelajaran dimana siswa pada kelas eksperimen pertama lebih banyak bertanya dibandingkan dengan siswa pada kelas eksperimen kedua. Pertanyaan yang diajukan adalah pengalaman-pengalaman sains yang siswa alami sehari-hari yang berkaitan dengan materi yang diajarkan.

Sedangkan pada model penalaran kausal berbasis sains modern, meskipun juga menuntun siswa untuk dapat menganalisis soal pemecahan masalah dan menyelesaikan soal dengan cara yang sistematis. Namun soal-soal pemecahan masalah fisika yang diberikan didasarkan pengetahuan sains barat. Sehingga menyulitkan siswa, karena siswa harus terlebih dahulu mengerti tentang contoh yang diberikan sebelum mengerti konsep dari materi itu sendiri. Hal ini disebabkan karena contohcontoh yang diberikan terkesan jauh dari kehidupan sehari-hari siswa. Contoh-contoh sains yang ada dalam sains modern lebih mengarah pada sains ilmiah atau kebudayaan dan kebiasaan sains barat yang bukan merupakan kebudayaan asli siswa.

Penelitian ini menunjukkan bahwa terdapat perbedaan yang signifikan antara kedua kelas eksperimen tentang kemampuan pemecahan masalah. Kemampuan pemecahan masalah fisika pada penelitian ini mengacu pada pedoman yang dikemukakan oleh Hung dan Jonassen ${ }^{[7]}$. Dimana siswa melakukan tahapan yang meliputi identifikasi masalah, mencari hubungan sebab akibat (kausal) dari variabel masalah, dan memecahkan masalah dengan bantuan diagram pengaruh. Pemecahan masalah yang 
dilakukan secara sistematis seperti ini diharapkan dapat menuntun siswa untuk dapat memahami konsep dan prinsip fisika.

Penerapan model penalaran kausal pada kegiatan pembelajaran ternyata dapat meningkatkan kemampuan memecahkan masalah fisika. Hal ini sesuai dengan hasil penelitian Hun dan Jonassen ${ }^{[7]}$ yang menunjukkan model penalaran kausal dapat meningkatkan kemampuan memecahkan masalah dan pemahaman mahasiswa tentang gerak rotasi pada mahasiswa Universitas Missouri Colombia. Serta hasil penelitian Nurjannah ${ }^{[9]}$ yang menunjukkan bahwa model penalaran kausal lebih baik jika dibandingkan dengan kolaborasi terstruktur dalam meningkatkan kemampuan memecahkan masalah medan magnetik pada mahasiswa calon guru program Studi Pendidikan Fisika FKIP Universitas Tadulako. Selain itu, Aikenhead dan Jegede ${ }^{[1]}$ mengemukakan bahwa keberhasilan proses pembelajaran IPA Khususnya fisika di sekolah sangat dipengaruhi oleh latar belakang yang dimiliki oleh siswa atau masyarakat tempat sekolah berada.

Meskipun dalam penelitian ini penerepan etnosains yang digunakan didasarkan terhadap latar belakang budaya kaili, namun siswa yang menjadi objek penelitian terdiri dari berbagai latar belakang suku (kaili, bugis dan arab). Hal ini dianggap tidak mempengaruhi penelitian karena didasarkan pada penelitian yang dilakukan oleh peneliti sebelumnya. Aikenhead dan Jegede ${ }^{[1]}$, menyatakan bahwa keberhasilan proses pembelajaran IPA khususnya fisika di sekolah sangat dipengaruhi oleh latar belakang budaya yang dimiliki oleh siswa atau masyarakat tempat sekolah berada. Dimana sekolah tempat siswa belajar berada dilingkungan masyarakat suku kaili, termasuk siswa yang bukan etnis kaili dalam kehidupan sehariharinya sering berinteraksi dengan masyarakat dan budaya kaili.

Terdapat faktor yang menjadi kelemahan mendasar dalam penelitian ini. Kelemahan yang maksud adalah kurangnya referensi budaya kaili yang berhubungan dengan sains. Terutama yang menyangkut materi tentang suhu dan kalor. Selain itu, budaya kaili yang memiliki hubungan dengan sains yang digunakan dalam pelaksaan pembelajaran ini kebanyakan merupakan budaya kaili yang hanya berhubungan dengan sains-sains dasar.

\section{KESIMPULAN}

Berdasarkan hasil penelitian dan analisis data hasil penelitian, maka dapat disimpulkan bahwa terdapat perbedaan kemampuan memecahkan masalah fisika antara model penalaran kausal berbasis etnosains dan model penalaran kausal berbasis sains modern. Hal ini dapat diketahui melalui hasil pengujian hipotesis dengan menggunakan uji-t dua variabel bebas dimana ho ditolak dan hi diterima.

\section{Kepustakaan}

[I] Aikenhead, G. S., \& Jegede, O. J. I999. "Cross-cultural Science Education: a Cognitive Explanation of a Cultural Phenomenon", dalam Journal of Research in Science Teaching.

[2] Poedjiadi, Anna. (2010). Sains Teknologi Masyarakat. Bandung : Rosda.

[3] Suastra,I.W. 2005. Merekonstruksi Sains Asli dalam Rangka Mengembangkan Pendidikan Sains Berbasis Budaya Lokal di Sekolah. Disertasi. Tidak Dipublikasikan.

[4] Carey, S. (2002). The Origin of Concepts: Continuing the Conversation. In N. L. Stein, P. J. Bauer, \& M. Rabinowitz (Eds.), Representation, Memory, and Development: Essays in honor of Jean Mandler (pp. 43-52). Mahwah, NJ: Erlbaum.

[5] Sunyono, Aryono. 1985. Kamus Antropologi. Akademika Pressindo. Jakarta.

[6] Kelley, H. H. (1973). The Process of Causal Attribution. American Psychologist, 28, 107-128.

[7] Hung, and Jonassen. (2006). "Conceptual Understanding of Causal Reasoning in Physics". International Journal of Science Education. 28, (13), I60I-I62I.

[8] Sugiyono. 2009. Metodologi Penelitian Pendidikan (pendekatan Kunatitatif, Kualitatif, dan R\&D). Bandung: Alfabeta.

[9] Nurjannah. (2008). Pengatuh Penggunaan Model Penalatan Kausal dan Kolaborasi Terstruktur terhadap Kemampuan Mahasiswa Calon Guru dalam Memecahkan Masalah Medan Magnetik. Proceeding of The Second International Seminar on Science Education. Pendidikan IPA SPs UPI, Bandung, 2008. 
Peningkatan kemampuan memecahkan masalah antara model penalaran kausal berbasis etnosains dan sains modern 